\title{
Analisis Collaborative Governance Dalam Penerapan Elektronik Kesehatan (E-Kes) Di Kabupaten Bengkulu Tengah
}

\section{Collaborative Governance Analysis in the Application of Electronic Health (E-Kes) in Bengkulu Tengah Regency}

\author{
Deni Triyanto1) *, Soehito Efendi1) \& Veny Puspita ${ }^{2)}$
}

1) Administrasi Publik, Fakultas Ilmu Sosial dan Ilmu Politik, Universitas Prof Dr Hazairin SH, Indonesia

2) Manajemen, Fakultas Ekonomi, Universitas Prof Dr Hazairin SH, Indonesia

Diterima: 16 September 2020; Disetujui:14 Desember 2020; Dipublish: 31 Januari 2021

\begin{abstract}
Abstrak
Tujuan Peneltian ini yaitu menganalisis Collaborative Governance dalam penerapan e-kes di Kabupaten Bengkulu Tengah, dengan menggunakan metode Penelitian deskriptif Kualitatif dengan indikator dari network structure, commitment to a common purpose, trust among the participants, dan access to resources". Teknik pengumpulan data melalui wawancara, observasi dan dokumentasi. Informan penelitian ini yaitu Sekertaris Dinas Provinsi Bengkulu, Kabupaten dan pejabat berwenang, pelaksana kebijakan, Kepala Puskesmas, Oprator Puskesmas. Hasil penelitian mengungkapkan bahwa network structure pada kolaborasi penerapan E-Kes cukup baik seperti sudah adanya pembangian otoritas kewenangan sesama stakeholeder baik dari puskesmas, rumhah sakit, Dinas Kesehatan kabupaten dan dinas Kesehatan Provinsi Bengkulu, commitment to a common purpose komitmen stakeholder cukup baik, trust among the participants, kepercayaan sesama stakeholders kurang baik dikarena infrastruktur penerapan e-kes kurang mendukung, access to resources bidang teknologi informasi yang terlibat kurang optimal di tingkat puskesmas. Kesimpulan bahwa kolaborasi penerapan e-kes di Kabupaten Bengkulu Tengah belum optimal dikarena beberapa indikator masih ditemukan permasalahan pada penerapannya.

Kata Kunci: Collaborative governance, E-Kes, Kabupaten Bengkulu Tengah
\end{abstract}

Abstract

The purpose of this research is to analyze collaborative governance in the application of e-kes in Bengkulu Tengah Regency, using descriptive qualitative research methods with indicators of network structure, commitment to a common purpose, trust among the participants, and access to resources ". Data collection techniques through interviews, observation and documentation. The informants of this research are the Secretary of the Bengkulu Provincial Office, the Regency and the authorized officials, policy implementers, the Head of the Puskesmas, and the Puskesmas Operators. The results of the study revealed that the network structure on the collaboration in implementing E-Kes is quite good, such as the development of authority and authority among stakeholders, both from health centers, hospital hospitals, district health offices and Bengkulu Province health offices, commitment to a common purpose, stakeholder commitment is quite good, trust among The participants said that the trust among stakeholders was not good because the infrastructure for implementing e-kes was not supportive, the access to information technology resources involved was not optimal at the health center level. The conclusion is that the collaboration in implementing e-kes in Bengkulu Tengah Regency is not optimal because several indicators still find problems in its application.

Keywords: Collaborative governance, E-Healty, Bengkulu Tengah Regency

How to Cite: Triyanto, D. Efendi, S. \& Puspita, V. (2021). Collaborative Governance Analysis In The Application of Electronic Health (E-Kes) in Bengkulu Tengah Regency. PERSPEKTIF, 10 (1): 211-217
*Corresponding author:
E-mail: dtriyanto992@gmail.com
ISSN 2085-0328 (Print)
ISSN 2541-5913 (online) 


\section{PENDAHULUAN}

Pemerintah Provinsi Bengkulu melalui Dinas Kesehatan Provinsi Bengkulu sampai saat ini melakukan perbaikan pada tata kelolah pemerintahan berbasis teknologi informasi dan dimasukkan menjadi program prioritas Provinsi Bengkulu. Salah satu manfaat dari penerapan e-government yaitu dapat mempermudah dalam memberikan pelayanan publik dan mempermudah pekerjaan pemerintah sebagai penyelenggara, Sistem informasi terpadu bidang kesehatan yang dibuat oleh Dinas Kesehatan Provinsi Bengkulu merupakan bagian dari e-government ini disebut e-kes, e-kes yang dibuat oleh Dinas Kesehatan Provinsi Bengkulu telah diterapkan di 177 Puskesmas di Provinsi Bengkulu. Dengan munculnya aplikasi e-kes diharapkan dapat membantu dalam memetakan SDM, sarana prasarana, pelayanan kesehatan dari tingakat puskesmas sampai dengan Rumah Sakit di Provinsi Bengkulu, bisa di petakan dengan baik mulai dari ketersediaan SDM di Puskesmas, sarana-prasarana peralatan hingga jenis penyakit. Dengan melihat tujuan dan manfaat E-Kes yang dikelolah Dinas Kesehatan Provinsi Bengkulu, maka penelitian ini ingin mengkaji kolaborasi dalam penerapan E-Kes di Provinsi Bengkulu.

Collaborative governance dapat dilaksanakan oleh pemerintah daerah dalam rangka menyelesaikan suatu masalah publik dengan melakukan kolaborasi dengan pihak lain yang terkait dalam proses penyelesaian masalah tersebut. Dalam kaitannya dengan Administrasi Publik, collaborative governance merupakan salah satu model strategi baru dari pemerintahan yang melibatkan berbagai stakeholders atau pemangku kepentingan secara bersamaan di dalam sebuah forum dengan aparatur pemerintah untuk membuat keputusan bersama yang bertujuan untuk menyeselesaikan masalah yang tidak bisa dihadapi sendirian oleh pemerintah itu sendiri." (Harmiati, Alexsander, Triyanto, Maya, \& Riastuti, 2020)

Collaborative governance dalam penerapan elektronik kesehatan (e-kes) di Kabupaten Bengkulu Tengah dikarenakan program ini merupaka program yang dibuat oleh provinsi yang harus diterapkan diseluruh Kabupaten/Kota, yang membutuhkan kolaborasi antar stakeholders untuk mengoptimalkan penerapannya, selain itu faktor otonomi daerah juga sangat mempengaruhi dikarena setiap daerah memiliki ego sektoral dan teritorial tersendiri.

Di era revolusi industri 4.0 duntuk memperbaiki tata kelola pemerintahan dibutuhkan digitalisasi untuk meningkatan efesiensi baiaya, waktu dan sumberdaya yang dimiliki setiap daerah. (Suyono \& Pramono, 2010) menyatakan bahwa secara tradisional, sektor publik adalah sektor yang relatif tidak leluasa dalam berhubungan dengan inovasi dibandingkan dengan sektor bisnis. Sejarah dan karakteristik organisasi sektor publik yang cenderung statis, formal, dan rigid menimbulkan keengganan sektor publik dalam memanfaatkan inovasi. Di sisi lain, sektor bisnis didorong untuk terus menghasilkan profit demi keberlangsungan hidupnya, sedangkan sektor publik cenderung statis karena merasa tidak ada yang perlu dikejar untuk mempertahankan keberlangsungan hidup organisasi.

Kabupaten Bengkulu Tengah merupakan Kabupaten penyanggah diharapkan diharapkan inovasi tata kelolah pemerintahan dapat menyimbangi Pemerintahan Kota Bengkulu, sehingga daerah tersebut juga dapat meningkatkan kinerja pelayanan publik, hanya saja perubahan-perubahan kearah digitalisasi ini tidak mudah dikarena bayak beranggapan bahwa perubahan itu tidak selamanya membawa dapak baik, sehingga munculah ketakutan-ketakutan yang sebenarnya tidak perlu menjadi masalah besar sebuah organisasi.

(Witanti \& Abdillah, 2018), menyatakan bahwa sistem dalam sektor publik berkarakteristik status-quo dan dan tidak menyukai perubahan. Bahkan tidak hanya dalam konteks kelembagaan, bahwa secara individu pun sangat jarang menjadikan inovasi sebagai bagian dari keseharian kerjanya. Pada umumnya individu yang terlibat di sektor publik hanya menjalankan tusinya secara biasa-biasa saja (business as usual). Kondisi ini mungkin juga dipengaruhi oleh belum adanya sistem reward and punishment yang diterapkan secara objektif dalam organisasi sektor publik. Hal ini menyebabkan individu tidak termotivasi untuk dapat berprestasi atau berkinerja lebih baik lagi.

Manfaat pada penerapan program E-Kes tersebut yaitu membantu pemerintah dalam memetakan SDM, sarana prasarana, pelayanan kesehatan dari tingkat Puskesmas sampai 
dengan Rumah Sakit di Provinsi Bengkulu. Apabila penerapan E-Kes di Kabupaten Bengkulu Tengah dapat diterapkan dengan optimal maka Dinas Kesehatan Provinsi Bengkulu dapat menganalisis ketersediaan SDM di Puskesmas untuk lima tahun yang akan datang, sarana-prasarana Puskesmas, peralatan medis, jenis penyakit yang ada pada pasien di Puskesmas, Rumah sakit dan pelayanan kesehatan berbasis elektronik yang dapat di akses masyarakat dimanapun. Hal tersebut menjadi dasar Dinas Kesehatan Provinsi Bengkulu dalam membuat sebuah program E-Kes untuk meminimalisisr penumpukan sumberdaya dibawah Dinas kesehatan Kabupaten Bengkulu Tengah dan Kabupaten/Kota Lainnya.

Berdasarkan penelitian terdahulu Proses kolaborasi dilakukan untuk mengatasi masalah anggaran dan penguatan antar instansi terkait dalam pengembangan inovasi e-government. Proses e-literacy dilakukan untuk meningkatkan partisipasi masyarakat dan pengembangan sumber daya manusia dengan cara sosialisasi kepada masyarakat, training of trainers, dan studi banding (Rozikin, Hesty, \& Sulikah, 2020), selanjutnya menurut hasil penelitian terdahulu bahwa keberhasilan collaborative governance, yaitu (1) jaringan tidak ada dominasi peran (2) para aktor memiliki komitmen mencapai tujuan yang sama (3) saling membangun kepercayaan (4) terdapat batas dan aturan yang jelas (5) otoritas, akuntalibitas, dan responsibilitas setiap aktor sesuai dengan peran masingmasing (6) penyampaian informasi melalui sosialisasi langsung dan media massa. Adapun upaya untuk meningkatkan kolaborasi dilakukan melalui penguatan kolaborasi dan komunikasi lintas sektor, advokasi, pengoptimalan Strategi Rencana Aksi Daerah (SRAD), testimoni dan peningkatan SDM (Rahmawati \& Dewi, 2018).

Proses collaborative governance belum optimal dilaksanakan, hal ini ditandai dengan adanya hambatan yang terjadi yaitu belum ada forum komunikasi, masih terdapat ego sektoral, keterbatasan sumber daya, dan keterlibatan swasta yang kurang maksimal (Arianti \& Satlita, 2018).
Sejalan dengan penelitian terdahulu dan pentingnya manfaat collabotrative governance pada penerapan E-Kes di Kabupaten Bengkulu tengah dengan penulis menggunakan teori Menurut DeSeve dalam (Sari, Sudarmo, Suharto, \& Dary, 2018), dengan mengambil 4 indikator yaitu collaborative governance yaitu "Network Structure, Commitment to a Common Purpose, Trust among the participants, dan Access to Resources".

\section{METODE PENELITIAN}

Metode Penelitian yang digunakan yaitu metode penelitian kualitatif tipe penelitian ini yaitu deskriptif (Moleong, 2011). Fokus penelitian ini yaitu pada Collaborative Governance pada penerapan E-Kes di Kabupaten Bengkulu Tengah. Lokus penelitian ini yaitu Kabupaten Bengkulu Tengah.

Instrumen utama pada penelitian ini adalah peneliti sendiri dan didukung oleh instrumen penunjang seperti pedoman wawancara, studi dokumentasi. Manfaat instrumen penunjang yaitu untuk melengkapi kelemahan dari instrumen peneliti sendiri (Creswell, 2018)

Data sekunder yang digunakan adalah studi dokumen atau literatur. Sumber sekunder diartikan sebagai sumber sejarah, biografi, ensiklopedi dan buku-buku referensi lain, esaiesai, buku-buku dan artikel-artikel yang dilaporkan atau diinterpretasikan dalam karya tulis oleh pihak lain atau pihak kedua. Unit analisis penelitian ini yaitu Dinas Kesehatan Provinsi Bengkulu, Dinas Kesehatan Kabupaten Bengku Tengah dan Puskesmas Rawat Inap Kabupaten Bengkulu Tengah. Informan penelitian ini yaitu Sekertaris Dinas Provinsi Bengkulu, Kabupaten dan pejabat berwenang, pelaksana kebijakan, Kepala Puskesmas, Oprator Puskesmas.

\section{HASIL DAN PEMBAHASAN \\ Analisis Collaborative Governance Dalam Penerapan Elektronik Kesehatan (E-Kes) Di Kabupaten Bengkulu Tengah}

Collaborative governance dapat

diterapkan oleh pemerintah daerah bertujuan untuk memecahkan permasalah-permasalahan tata kelola pemerintahan, dengan cara melakukan kolaborasi dengan para stakeholders terkait permasalahan tersebut. Berkaitan dengan Administrasi Publik, collaborative governance merupakan salah satu 
model strategi baru dari pemerintahan yang melibatkan berbagai stakeholders atau pemangku kepentingan secara bersamaan di dalam sebuah forum dengan aparatur pemerintah untuk membuat keputusan bersama yang bertujuan untuk menyeselesaikan masalah yang tidak bisa dihadapi sendirian oleh pemerintah itu sendiri (Febrian, 2016).

Berhasil tidaknya collaborative governance menurut DeSeve dalam (Sari et al., 2018), pada penelitian ini mengambil 4 indikator yaitu "Network Structure, Commitment to a Common Purpose, Trust among the participants, dan Access to Resources".

\section{Network Structure (Struktur Jaringan)}

Network Structure atau struktur jaringan yang artinya harus memilik struktur jaringan yang jelas apabila penerapan e-kes di Kabupaten Bengkulu Tengah supaya optimal, berdasarkan hasil penelitian merangkan bahwa keterlibatan stakeholeders di Kabupaten Bengkulu sangat rendah, sedangkan dibutuhkan partisipasi yang baik jika ingin penerapan e-kes optimal, dikarenakan setiap lini membutuhkan kerjasam yang baik dari tingat Dinas Kesehatan, Rumah Sakit dan Puskesmas.

Selain itu menurut (Triyanto \& Efendi, 2019), bahwa rendahnya partisipasi dikarenakan regulasi penerapan electronic government (e-gov) di Kabupaten Bengkulu Tengah belum jelas sehingga penerapan e-Kes juga belum optimal, regulasi mengenai $e$ government di Kabupaten Bengkulu Tengah masih menginduk pada Peraturan Gubernur Nomor 17 Tahun 2018 tentang master plan $e$ government, sehingga wajar apabila penerapan e-kes saat ini belum optimal. penerapan $e$ government itu layak atau tidaknya juga dipengaruhi oleh peraturan pemerintah daerah tentang e-government.(Surdin, 2016)

Pembagian otoritas pada penerapan ekes di Kabupaten Bengkulu Tengah cukup jelas, Dinas Kesehatan Kabupaten Bengkulu Tengah memiliki tanggungjawab merekap laporan dari sistem e-kes yang dilaporkan oleh Rumahah Sakit dan Puskesmas, setelah itu Dinas Kesehatan Kabupaten Bengkulu Tengah mendistribusikan melalui e-kes ke Dinas Kesehatan Provinsi Bengkulu, sehingga terintegrasi dengan baik. Sesuai dengan hasil wawancara dengan Informan $(15 / 07 / 2020)$, bahwa :

"Pembagian otoritas dari Dinas Provinsi, Kabupaten, Rumah sakit, dan Puskesmas sudah jelas sistemnya seperti ini kami pihak Dinkes Kabupaten hanya merekap dari laporan atau yang diinput oleh pihak RS dan Puskesmas baru opratorkami merekap dan melaporkan ke Dinas Kesehatan Provinsi nanti jika data sudah valid maka akan ditampilkan pada sistem e-kes."

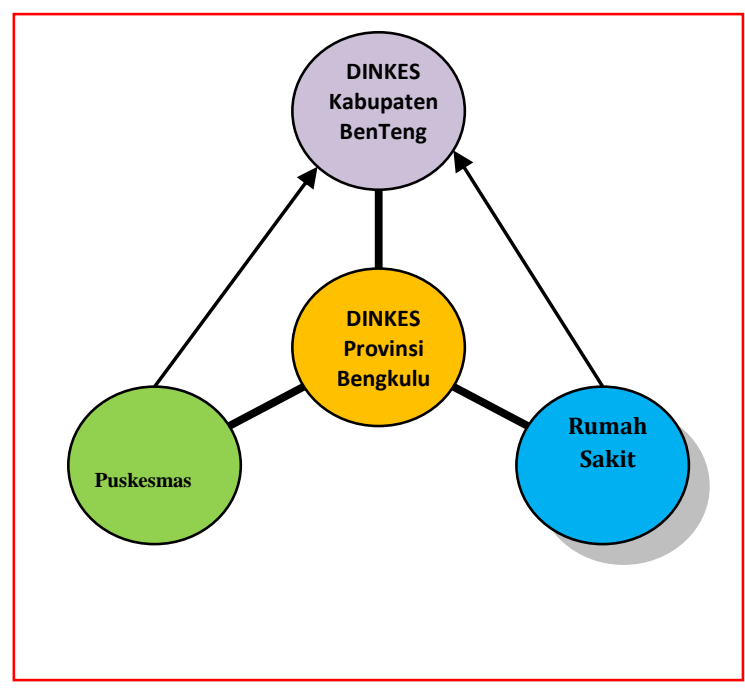

Gambar 1. Proses Pembagian Otoritas Penerapan e-kes di Kabupaten Bengkulu Tengah (Sumber : analisis hasil Penelitian 2020)

Commitment to a Common Purpose (Komitmen Terhadap Tujuan)

Komitmen adalah landasan terpenting dalam kolaborasi penerapan e-kes di Kabupaten Bengkulu Tengah, karena dengan adanya komitmen yang terjalin baik antar stakeholders Kabupaten dan provinsi permasalahan permasalahan yang timul pada saat penerapan e-kes dapat di Kabupaten Bengkulu Tengah. Komitmen yang dilakukan oleh Dinas Kesehatan Kabupaten Bengkulu Tengah dengan cara mendukung perbaikan infrasturktur e-kes secara berkelanjutan, supaya penerapan e-kes di Kabupaten Bengkulu Tengah dapat berjalan dengan baik. Namun untuk tingakat Puskesmas belum dapat diperbaiki dalam retang waktu 2 tahun ini dikarena kendala dengan sumberdaya finansial dan sumberdaya manusia yang mahir dibidang teknologi informasi.

Sejalan dengan pernyataan informan dari Dinas Kesehatan Kabupaten Bengkulu Tengah, $(20 / 07 / 2020)$ : 
"Komitmen kami tunjukkan dengan melengkapi sarana dan prasarana yang ada di Dinas Kesehatan Kabupeten Bengkulu Tengah, namun untuk tingkat Puskesmas kami belum bisa menghendel keseluruhan dikarenakan Sumber daya manusia IT yang terbatas dan tentunya dana yang kami ajukan tidak bisa semua fokus ke e-kes, apalagi saat ini Dinkes masih Fokus Pada Covid-19)"

Diperkuat juga dengan pernyataan oleh Informan di Puskesmas Rawat inap Kabupeten Bengkulu Tengah $(21 / 07 / 2020)$ :

"Komitmen kami sangat besar apabila ekes ini dapat diterap dengan optimal, karena tata kelolah pemerintahan akan baik, tenaga kesehatan tidak menumpuk pada daerahdaerah maju saja, namun di puskesmaspuskesmas lain jg dapat merata, hanya saja untuk infrastruktur belum mendukung, sumberdaya manusia" yang lulusan IT juga terbatan, nunggu rekrutmen masih gak tau tergantung daerah dan pusat".

Komitmen para stakeholders Kabupaten Bengkulu Tengah sangat baik hanya saja untuk sumber daya pendukung komitmen itu belum optimal sehingga kendala-kendala masih terdapat pada penerapan e-kes.

\section{Trust among the participants (Adanya Kepercayaan sesama Stakeholder)}

Kepercayaan sesama stakeholders adalah salah satu indikator penting dalam penerapan e-kes di Kabupaten Bengkulu Tengah. Berdarakan hasil dari analisis hasil penelitian bahwa kepercayaan stakeholders dalam penerapan E-Kes di Puskesmas Kota Bengkulu belum optimal, (2/8/2020) :

"Kepercayaan yang terbangun sesama stakeholeders belum maksimal, dikarenakan untuk di Kabupawtwn kita kan harus berurusan kesetiap puskesmas dan letak geografis sangat beragam masih ada puskesmas yang plosok, sehingga kepercayaan meraka terhadap penerapan e-kes ini belum terbangun karena mereka mikir sarana dan prasaran belum lengkap, internet masih susah padahal kami salah satu Kabupaten Penyanggah Kota tapi realitanya masih seperti ini"

Pentingannya kepercayaan stakeholders dalam penerapan e-kes, yaitu dengan adanya kepercayaan sesama stakeholders terkait maka mereka dapat bekerja maksimal dan optimis namun ketika sarana prasarana dan pendukung kurang memadai maka kepercayaan terhap penerap e-kes juga kurang maksimal. Selain itu juga peran Dinas Kesehatan Provinsi Bengkulu juga belum maksimal sesuai dengan hasil wawancara dengan informan, (wawancara : 23/7/20120) :

"Tingkat Kepercayaan Masih rendah dikarena Provisi hanya membuat program setelah itu melakukan sosialisasi hanya sekali dan tidak pernah memikirkan bagaimana sumberdaya manusia, financial, sarana dan prasaranya yang ada di Kabupaten"

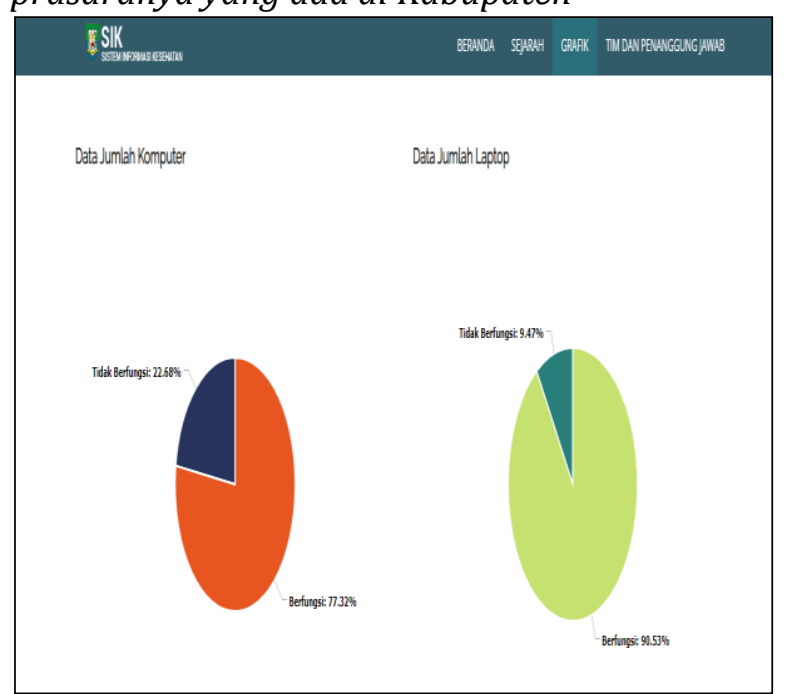

Gambar 2. Kondisi Infrastruktur TI (Sumber https://dinkesbengkulu.com/)

Sarana dan Prasarana pendukung berbasis digital merupakan indikator penting dalam penerapan E-Kes di Kabupaten Bengkulu tengah apabila infrastruktur telah memadai maka tingkat kepercayan sesama stakeholders terhadap keberhasilan e-kes ini tinggi, namun apabila sarana prasara, sumberdaya manusia minim tingkat kepercayaan yang terbagun juga rendah. Minimnya sumberdaya manusia yang memumpuni dibidang IT menjadi permasalahan dalam penerapan e-government (Sampama, 2016).

\section{Access to Resources (Akses terhadap sumberdaya)}

Sumberdaya Manusia yang tersedia di Di Dinas Kesehatan Kabupaten Bengkulu Tengah cukup baik dikarena telah mempunyai oprtor yang handal untuk menegelolah e-kes, untuk tingkat rumah sakit dan Puskesmas yang ada di Kabupaten bengkulu Tengah yang menguasai e-kes belum maksimal, sehingga penerapan ekes kurang maksimal. Seharusnya di setiap Puskesmas memiliki satu oprator SIK untuk EKes yang bertugas di pelaporan pelayanan terpadu dimana memiliki background 
pendidikan umum/ bukan lulusan dari informatika/sistem informasi atau sejenisnya sehingga tidak profesional di bidang TI, selain itu untuk pemaksimalkan penerapan e-kes ini juga Provinsi tidak dapat mendistribusikan pihak IT karena adanya batasan kewenangankewenagan tingkat provinsi.

Wujud Kolaborasi Stakeholder yang diidamkan adalah kolaborasi yang dapat memecahkan masalah-masalah yang ada pada penerapan E-Kes di Kabupaten Bengkulu Tengah. Rendahnya partisipasi stakeholders karena permasalahan kurangnya koordinasi yang dibentuk oleh Dinas Kesehatan Provinsi Bengkulu, padahal meningkatkan partisipasi stakeholder ini merupakan cara terbaik dalam menerapkan E-Kes. Bentuk kolaborasi yang baik adalah kolaborasi yang memiliki visi dan misi yang berkelanjutan sehingga dapat mencapai tujuan bersama (Harmiati, Henny Aprianty, Supriyono, Deni Triyanto, 2018)

Berikut ini model kolabotrasi yang ideal untuk menerapkan e-kes di Kabuupaten Kabupaten Bengkulu yang ideal

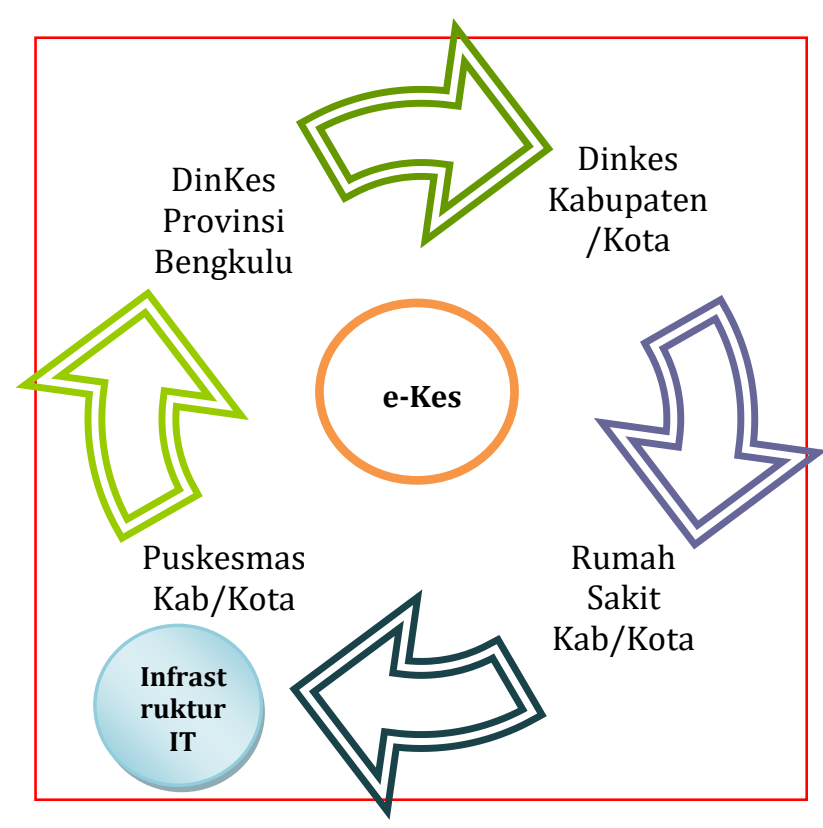

Gambar 3. Model Kolaborasi Penerapan e-Kes di Kabupaten Bengkulu Tengah (Sumber : analisis hasil Penelitian 2020)

\section{SIMPULAN}

Kolaborasi stakeholder dalam penerapan e-kes di Kabupaten Bengkulu Tengah dapat di simpulkan belum optimal, dapat dilihat dari indikator Network Structure, Commitment to a Common Purpose yaitu pembagian otoritas pada penerapan e-kes di Kabupaten Bengkulu Tengah cukup jelas, Dinas Kesehatan Kabupaten Bengkulu Tengah memiliki tanggungjawab merekap laporan dari sistem ekes yang dilaporkan oleh Rumahah Sakit dan Puskesmas, setelah itu Dinas Kesehatan Kabupaten Bengkulu Tengah mendistribusikan melalui e-kes ke Dinas Kesehatan Provinsi Bengkulu.

Commitment to a Common Purpose (Komitmen Terhadap Tujuan), Sarana dan Prasarana pendukung berbasis digital merupakan indikator penting dalam penerapan E-Kes di Kabupaten Bengkulu Tengah apabila infrastruktur telah memadai maka tingkat kepercayan sesama stakeholders terhadap keberhasilan e-kes ini tinggi, namun apabila sarana prasarana, sumberdaya manusia minim tingkat kepercayaan yang terbagun juga rendah karena untuk mendigitalisasi tata kelola pemerintahan harus siap sumberdaya yang baik. Minimnya sumberdaya manusia yang memumpuni dibidang IT menjadi permasalahan dalam penerapan e-government (Sampama, 2016). dan Access to Resources (Akses terhadap sumberdaya) yaitu Sumberdaya Manusia yang tersedia di Di Dinas Kesehatan Kabupaten Bengkulu Tengah cukup baik dikarena telah mempunyai oprtor yang handal untuk menegelolah e-kes, untuk tingkat rumah sakit dan Puskesmas yang ada di Kabupaten bengkulu Tengah yang menguasai e-kes belum maksimal, sehingga penerapan ekes kurang maksimal. Seharusnya di setiap Puskesmas memiliki satu oprator SIK untuk EKes yang bertugas di pelaporan pelayanan terpadu dimana memiliki background pendidikan umum/ bukan lulusan dari informatika/sistem informasi atau sejenisnya sehingga tidak profesional di bidang $\mathrm{TI}$, selain itu untuk pemaksimalkan penerapan e-kes ini juga Provinsi tidak dapat mendistribusikan pihak IT karena adanya batasan kewenangankewenagan tingkat provinsi.

\section{UCAPAN TERIMAKASIH}

Terimakasih kepada Lembaga Penelitian Pengabdian Kepada Masyarakat (LPPM) Universitas Prof. Dr. Hazairin, SH Bengkulu yang telah men-support penelitian ini yang telah membantu dalam pelaksanaan penelitian dan penulisan manuskrip ini. 


\section{DAFTAR PUSTAKA}

Arianti, D., \& Satlita, L. (2018). Collaborative Governance Dalam Pengembangan Konservasi Mangrove Baros Di Desa Tirtohargo Kecamatan Kretek Kabupaten Bantul, 6(2): 809-827.

Creswell, J. W. (2018). Research Design Qualitative, Quantitative, and Mixed Methods Approaches (Second Edi). London: University of Nebraska.

Febrian, R. A. (2016). Collaborative Governance Dalam Pembangunan Kawasan Perdesaan (Tinjauan Konsep dan Regulasi ), II(2), 200208.

Harmiati, Aprianty, H., Supriyono, Deni Triyanto, A. (2018). Implementasi Good Enviromental Governance dalam Pengelolaan Daerah Aliran Sungai ( Das ) Bengkulu. JIP, 3(2), 136148.

https://doi.org/http://dx.doi.org/10.24905 /jip.v3i2.1003

Harmiati, A, Triyanto, D., Maya, M., \& Riastuti, F. (2020). Analisis Pemetaan Collaborative Governance Dalam Program Keluarga Berencana Di Kota Bengkulu. Mimbar : Jurnal Penelitian Sosial Dan Politik, 9(1): 1-11.

Moleong, L. J. (2011). metodologi penelitian kualitatif , Jakarta: ROSDA KARYA.

Rahmawati, L., \& Dewi, U. (2018). Dinamika Collaborative Governance Dalam Penanggulangan Hiv Dan Aids Di Kota Yogyakarta Dynamics Collaborative Governance For Hiv / Aids Prevention In, 7(3): 203-216.
Rozikin, M., Hesty, W., \& Sulikah. (2020). Inovasi EGovernment Pemerintah Daerah Collaboration And E-Literacy: Key Success Innovation Of Local E-Government, 16(1), 61-80.

Sampama, A. (2016). Penerapan E-Government Dinas Kesehatan Provinsi Kalimantan Timur Dalam Memenuhi Kebutuhan Informasi Masyarakat Di Samarinda. eJurnal Ilmu Komunikasi, 4(4): 137-148. Retrieved from ejournal.ilkom.fisip-unmul.ac.id

Sari, F. A., Sudarmo, Suharto, D. G., \& Dary, N. H. (2018). Collaborative Governance : Managing Residential Areas In Malang Based on Public Private Partnership. IAPA, 7(2): 387-405.

Surdin, J. (2016). Analisis of E-Government Implementation Feasibility of Public Service in Agrarian Field at Pinrang Regency. Ilmu Komunikasi KREBA, 5(1): 178-191.

Suyono, D., \& Pramono, T. (2010). Bureaucracy Reformation In Regional Bureau Of Statistic Tulungagung Regency. Jurnal Ilmu Sosial Dan Ilmu Administrasi Negara, 2(2): 25-31.

Triyanto, D., \& Efendi, S. (2019). Analisis Penerapan Elektronik Kesehatan ( E-Kes ) di Puskesmas Rawat Inap Kota Bengkulu. Jurnal Administrasi Publik: Public Admnistration Journal, $\quad 9(2): \quad 158-165$. https://doi.org/http://dx.doi.org/10.31289 /jap.v9i2.2901

Witanti, W., \& Abdillah, G. (2018). Sistem Informasi Pelayanan Kesehatan Sebagai Upaya Peningkatan Kinerja E-Government, (November). 